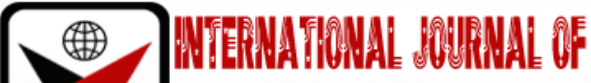 \\ בmas
}

ISSN 2278-0211 (Online)

\section{African Traditional Religious Values Crucial for Social Development of Ghana}

\begin{tabular}{|c|}
\hline Konadu Adam \\
Tutor, Department of Religious and Moral Education, \\
St. Ambrose College of Education, Dormaa, Ghana \\
Mensah Bonsu Frederick \\
Tutor, Department of Religious and Moral Education, \\
Wesley College of Education, Kumasi, Ghana \\
\hline
\end{tabular}

\begin{abstract}
:
Development is a holistic agenda that could to be tackled or targeted from different perspectives. Every human society seeks to achieve development as a way of realizing the essence of life. Religion as a human institution that has characterized our societies from the past to the present also has something to offer to ensure and promote development of our human society. There are values in almost all the religions in the world that ensure and promote development. African Traditional Religion which has defined and informed the religiosity of several Africans from the past to the present also has wholesome and precious values that if practicalized or patronized will ensure a formidable development of our society. Thus, this piece of scholarly work seeks to highlight some of such African traditional religious values that can ensure and promote social development.
\end{abstract}

Keywords: Development, Social development, Values, Religious values, Religion, African traditional religious values

\section{Introduction}

Religion and development are crucial issues or phenomena in the human society. The values that are established by the various religions are indomitable tools that can ensure development of the society. With regards to the African Traditional Religion, there are precious values that could ensure and enhance maximum social development. This essay seeks to highlight those African traditional religious values and how they can ensure holistic of the human society.

\section{Methodology}

This paper attempts to highlight the African traditional religious values capable of ensure social development in Ghana. This literary work is based on the study and scrutiny of various secondary data resources focusing on Religion and Development. Data from the internet, published and unpublished literature in the form of books, newspapers and journal articles were patronized. This study is necessary because it brings to light the traditional values inherent in Ghana from the past to the present that is capable of ensuring development of the human society. This will didactically inform the present and future generation to cherish the traditional values of the Ghanaian society.

\section{Definition of Terms}

For an adequate comprehension of this literary work, it is imperative to explain the terminologies that are at the heart of the topic. Such words are values, religious values, African traditional religious values, development and social development.

\subsection{Values}

Values refer to the standards or ideas which most people hold to be good or bad. In other words, values are the things that the individual or the society cherishes in life and are considered desirable. ${ }^{1}$ They are collective ideas about what is right or wrong, good or bad, and desirable or undesirable in a particular culture. ${ }^{2}$ For De Jong, values refer to the norms as these are taught and adhered to by the members of a particular religion. ${ }^{3}$ 


\subsection{African Traditional Religious Values}

Religious values belong to a broader category called culture defined as the collective programming of mind that distinguishes the members of one group (country or society) from another. ${ }^{4} \mathrm{African}$ traditional religious values refer to the standards or ideas which are held to be good or right in the African traditional societies. In other words, they are the norms as these are taught and adhered to by the members of the African Traditional Religion.

\subsection{Development}

Development is a holisticenterprise which aims at promoting the total wellbeing and the full potential of human beings. Development is release from what seals us in and holds us captive. It is a release from that which holds us back and prevents us from making complete progress. It is concerned not only with material but also moral, intellectual and spiritual needs of humans as well. ${ }^{5}$ Sustainable economic development involves putting in place substantive measures to ensure a state of society where living conditions and resource use continue to meet human needs without undermining the integrity and stability of the natural systems.

\subsection{Social Development}

Social development, as used in this work, refers to the holistic development of the human society. It encapsulates several things relating to humanity and the society. It is synonymous to societal development which refers to the formation and transformation of social life, customs and institutions. ${ }^{6}$ It also involves to an on-going refinement of existing behavioural patterns, feelings, attitude toward others, and understanding of others. ${ }^{7}$

\section{The Relation between Religious Values and Social Development}

Africans are notoriously religious, and each person has its own religious system with a set of beliefs and practices. Religion permeates into all the departments of life so fully that it is not easy or possible always to isolate. ${ }^{8}$ According to Mbiti, to ignore the traditional beliefs, attitudes and practices can only lead to a lack of understanding of African behaviour and problems. Religion is the strongest element in traditional background, and exerts probably the greatest influence upon the thinking and living of the people concerned. Therefore, to be without religion amounts to a self-excommunication from the entire life of society, and African peoples do not know how to exist without religion. ${ }^{9}$ Asare agrees with Mbiti as he indicates that the influence of religion is equally evident everywhere in the Ghanaian society. It influences their lives from birth to the grave. More importantly, it influences their way of thinking and their attitude to life. ${ }^{10} \mathrm{~A}$ study of these religious systems and their values is therefore ultimately a study of the peoples themselves in all the complexities of both traditional and modern life. For Chukwudum, the African holds certain things to be of great value in his traditional life. It is these values which give him a distinct cultural personality and enable him to make some contribution to world knowledge, history and civilization. The African wishes to retain his self-identity through retaining his traditional values. ${ }^{11}$

In the recent past, one can witness an increasing awareness of the role of values for economic development. For many, religion is by far the most important source of values. ${ }^{12}$ Hence, the role of religion in the development process is once again on the agenda. According to De Jong, the values adhered to by the members of each large religion change due to economic circumstances and pressure. Individual religious persons can be inspired by values taught and the history of his or her religion. Adherents of other religions have similar feelings and obtain aspiration from their religious sources. He adds that the results of some studies on the relation between culture and economic performance can illustrate how values influence institutions and governance, and result in a significantly different level of economic growth or development. Asante ${ }^{13}$ also emphasized the need to exhibit values in our economic life to ensure sustainable development. For him, human life is pervaded with economic matters. Economic life defines and informs the work we do, the income we receive and how much we consume or disburse and save. Human beings are responsible and accountable to economic life which is intended to be a means by which God's purpose and intentions for humankind and creation are to be served. Thus, the humans' life is in many ways defined and informed by economics. The human is homo economicusjust as the human is a religious being, homo religiousus. ${ }^{14}$ Thus, religion and development have more in common than is normally apparent. At the foundation, both are visions of how the world may be transformed. From a religious perspective, the transformation of individuals, or inner transformation, is deemed a necessary condition for transforming society and the world as a whole. Therefore, what most needs to be studied and integrated into the process of development are the religious ideas or values on which religious organizations are based and the inspiration that people derive from these.

\footnotetext{
${ }^{4}$ De Jong, Religious Values and Economic Growth: A review and assessment of recent studies

${ }^{5}$ Asante, E, 2007, Culture, Politics and Development: Ethical and Theological reflections on the Ghanaian experience. Ghana: Challenge Enterprise. p.10

${ }^{6} \mathrm{https}: / /$ www.dictionary.com/browse/societal-development. Accessed on 09/09/2021

${ }^{7}$ G. M. van der Aalsvoort, International Encyclopaedia of Education.Available at https://www.sciencedirect.com/topics/social-sciences/economic-andsocial-development. Accessed on 13/09/2021

${ }^{8}$ Mbiti, J. S., 1989. African Religions and Philosophy. $2^{\text {nd }}$ ed. 361 Hannover Street, Portsmouth: Heinemann Educational Books Inc. p.1

${ }^{9}$ Mbiti, African Religions and Philosophy. p.2

${ }^{10}$ Ebenezer O. A., 2010.Science, Religion and Man, Daily Graphic newspaper: Ghana, p.27

${ }^{11}$ Chukwudum B. O., Urbanization and African Traditional Values.Available at http://www.crvp.org/book/Series01/1-5/chapter_ix.htm.Accessed on $17 / 09 / 2021$.

12 De Jong, Religious Values and Economic Growth: A review and assessment of recent studies

${ }^{13}$ Asante E., The Role of the Church in the Economic History of Ghana - Past, Present and Prospects. A lecture delivered by Prof. Emmanuel Asante. p.1

${ }^{14}$ Asante E., The Role of the Church in the Economic History of Ghana - Past, Present and Prospects. p.1
} 


\section{African Traditional Religious Values That Can Ensure Social Development}

By our topic, we are considering some values in African Traditional Religion that can help in the sustainabledevelopment of our society. Some of such values are godliness, hospitality and respect for humanity, tolerance, humility and hard work. The discussion will consider how these values in African Traditional Religion can help in sustainable economic development of Africa, taking Ghana as a case study.

\subsection{Godliness}

The African is a religious being. There is a widespread belief in the existence of a Supreme Being in almost all the communities in Africa. This Supreme Being is regarded as the creator of the universe, and the provider and sustainer of life. The presence of God and the other deities are expressed through prayers, libation, and calling upon God in times of trouble. ${ }^{15}$ Looking at the African's perception of God and nature, Mbiti indicates that many concepts are reported which associate God with natural objects and phenomena. He adds thatAfricanpeople regard the universe as a religious universe, and this attitude is fully illustrated by the way they 'read' God into various objects and phenomena. ${ }^{16}$ For instance, rain is regarded by African people to be one of the greatest blessings of God. For that reason, God is commonly referred to as 'the Rain Giver'. Thunder is taken by many, such as the Ewes of Ghana, to be God's voice. ${ }^{17}$ In a few cases, the wind is associated with God. Some people describe God as being like the wind or air, or moving like the wind; and others think that the wind is one of the vehicles by which God travels in great powers through the sky. ${ }^{18} \mathrm{Mbiti}$ emphasized that in some areas, people personify rivers and streams, or attribute divinities or major spirits to them. The African values the whole of creation as sacred. Nature to him is not uncanny, nor is it for subjugation and exploitation, but something sacred, participating in the essential sacred nature of God Himself and of all reality. Open spaces, fields, forests, trees, oceans and lakes are sacred to him and consequently important as places reminiscent of the ashes of his fathers and the temples of his gods. ${ }^{19} \mathrm{Festivalsare}$ even celebrated to thank the spirits and to ensure the fertility of crops, for example Odwira and Adae festivals in Ghana.

From the background of such beliefs and convictions, the African sees no reason destroying, harming or doing anything uncivilized against the natural resources such as the wind, vegetation and water bodies. There are even taboos associatedwith such practices and they inhibit or prevent causing undue harm to the environment. Such religious beliefs and values prevent Africans from deteriorating or depleting the environment. Such practices have helped to ensure some forest reserves from which we can obtain trees for the production of wood that can be exported for foreign exchange. The herbs from these forest reserves also serve as source of medicine to improve the health condition and strength of the people and this can prepare them for economicdevelopment. The wildlife conservations help to raise animals that can be sources of food and foreign exchange. On this, Twumasi ${ }^{20}$ indicates that, if and when many people are sick in a society within a given time, it is disturbing to the normal functioning of the social system. Also, the spirit of godliness helps to raise God-fearing Africans who are trustworthy. This is because, trust and cooperation are often found to be positively associated with economic growth and development in Ghana.

\subsection{Unity / Togetherness / Belongingness}

African Traditional Religion promotes a way of life in which the philosophical outlook of the individual is embedded in the notion of 'I am because we are; and since we are, therefore I am' 21 and where the existence of the individual presupposes the existence of the community. Thus, African community values emphasize care for the other and living in according to communitarian norms, as the cornerstone for a healthy society rather than individualism and selfseeking. ${ }^{22}$ Moreover, according to Ayandokun, 'as Africans, there are certain values that are part of our culture which we must cherish, embrace and continue to pursue. One of such is brotherly love among members of same community. Africans live in communities and they are conscious of protecting each other'23.Each member of the society feels a loyalty and commitment to the society to the extent that members demonstrate their willingness to advance communal interest. ${ }^{24}$ This explains the proverb of the Akans of Ghana that 'the sticks of the broom cannot be broken when together'. Thus, the integration of individuality into community in African traditional society is so essential and thoroughgoing. 25

Progress and development are achieved through a united approach and effort. Having in mind the equality of humanity, people irrespective of the religious background come together and with one accord engage in meaningful activities with the aim of ensuring and promoting development in their society. ${ }^{26}$ This is because religious people living harmoniously together can lead to openness, which can break down mental and social barriers. Almost all these groups have a stake in the nation's socio-economic and cultural growth and development. It has also ensured increase in

\footnotetext{
${ }^{15}$ Ayertey, Mastering Social Studies, p.131

${ }^{16}$ Mbiti, African Religions and Philosophy. p.51

17 Mbiti, African Religions and Philosophy. p.53

${ }^{18}$ Mbiti, African Religions and Philosophy. p.53

${ }^{19}$ Chukwudum, Urbanization and African Traditional Values.

${ }^{20}$ Twumasi P. A., 1988, Social Foundations of the Interplay between Traditional and Modern Medical Systems. Ghana: Ghana Universities Press. p.2

${ }^{21}$ Mbiti, J. S., 1989. Introduction to African Religion, $2^{\text {nd }}$ ed. 361 Hannover Street, Johannesburg: Heinemann Publishers Ltd, p.141

${ }^{22}$ Gyekye K., 1992. 'Person and Community in African Thought' in Wiredu K. and Kwame, Gyekye (eds.) Person and Community: Ghanaian Philosophical

Studies 1. Washington: The Council for Research in Values and Philosophy.

${ }^{23}$ Ayandokun, E. O., 2012.'Building a Tension-free Society for Mutual Relationship: Our Religious Differences Notwithstanding', WAATI Papers No. 7 on

Christian-Muslim Relations in West Africa, p.108

${ }^{24}$ Gyekye K., 1987. An Essay on African Philosophical Thought: The Akan Conceptual Scheme, Cambridge: University Press, p.155

25Wiredu K., 1996. Cultural Universals and Particulars: An African Perspective, Bloomington and Indianapolis: Indiana University Press, p.71

${ }^{26}$ Konadu A., 2015. The Impact of Religious Pluralism on the Ghanaian Society: Case Study of the SekyereKumawu District in Ghana, UPK - KNUST, p.85. A

Thesis presented to the Kwame Nkrumah University of Science and Technology for the award of Master of Philosophy in Religious Studies.
} 
productivity and development as people of different religious backgrounds come together to embark on common economic activities geared towards development. ${ }^{27}$

\subsection{Hospitality}

One of the distinguishing values associated with the African Traditional Religion is hospitality, especially to strangers. Followers or practitioners of African Traditional Religion are required by tradition to be very friendly and hospitable, especially to strangers. No matter how rude the traditional Ghanaian may be, he or she will never deny a stranger water, food and shelter if he or she can provide them. ${ }^{28}$ In the Ghanaian society, greetings is cherished and considered a way of acknowledging the other person as a fellow human being. A person may feel deeply hurt if you pass him by without greeting him. ${ }^{29}$ So, a Ghanaian child is socialized to greet those he meets; even the stranger whom he may never meet again. ${ }^{30}$ This is indeed a good incentive for the attraction of foreign tourists and investors. The Akans of Ghana have an adage which goes like 'dibinamenni bi naemaohohoanikae' which implies good living makes the stranger stay comfortably. The Akans also say 'yedeahohonaekyekyerekuro' which implies that we use strangers or foreigners to build or develop a town. Thus, by virtue of such lucrative value as hospitality in African Traditional Religion, Ghanaians are able to enjoy the presence of foreign investors who invest their monies or capital into the country's economic activities.

\subsection{Respectfulness}

AfricanTraditional Religion advocates respect for authority, law, God, the disabled, the aged, foreigners or strangers and every manner of person. Normally, in the traditional Ghanaian societies, the child is given corporal punishment for being rude to an elderly person. ${ }^{31}$ Showing disrespect is regarded as immoral and hence abominable in the Ghanaian society. Religious upbringing and active religious participation increase trust toward government institutions and reduce the willingness to break any sort of legal rule. ${ }^{32}$ This is indeed a good incentive for the attraction of foreign investors. Thus, the virtue of respectfulness attracts people into Ghanaand even entices them to invest their resources in the nation'seconomy. According to De Jong, a channel by which religion influences society is by the values that are taught by the adherents or most importantly leaders of the religion concerned. These meetings can be instruments for establishing networks that could also be helpful for establishing trade relations with partners from other countries who belong to the same religious group. ${ }^{33}$ Such networks do stimulate economic growth.

The traditional Ghanaian respects human life and sees it as sacred. It is a taboo to abort a child or engage in some family planning practices. As a result of their respect for humanity, they cherish large families. Children are of supreme value to the African. His primary purpose for marriage is to have children and to have as many of them as possible. The fact is that, the African will count his blessing by the number of children he has. ${ }^{34}$ The large family size helps the parents or guardians to get enough labour force to engage in commercial activities such as large-scale farming. This goes a long way to increase productivity for sustainable economic development.

\subsection{Tolerance}

Tolerance is a value that every African traditional society upholds. Tolerance in this context refers to patience, longsuffering, and the willingness to respect other people's views and rights. When people tolerate one another and coexist in peace, development in the local community is possible. The community can act in unison, speak with one voice and policy makers will listen. It can also lead to the survival and development of the various religious communities. ${ }^{35}$ Thus, development can be ensured in the prevalence of peace and stability and strong collaboration between people irrespective of religious background. This value (tolerance) has masterminded the peace which Ghana is currently enjoying. On the economic front, Ghanaians are noted for having a spirit of tolerance for any policy, whether harsh or not, in so far as they hope to derive some satisfaction at a later period. ${ }^{36}$ They recognize the existence of different groups in the society and the need to sustain their own culture while attaching themselves to the country's society, values, and institutions. ${ }^{37}$ They see themselves as people who settle their differences peaceably and in a consultative rather than confrontational manner. There is the Akan traditional maxim which goes like 'obaakofonsanso Nyameani kata' meaning 'the hand or palm of one person cannot cover the face of God'. This implies that many hands must be on board to achieve a mission. There is also the saying that 'asembiaranniho a yenfayanonaeka' meaning 'all cases or disputes can be resolved by the word of mouth'.This makes Africans seek to settle issues peaceably and remedy the apparent lack of understanding among different groups and religions. This value has reduced or helped to manage inter-ethnic and interreligious conflicts in Africa. It has also enhanced pluralism and cooperation in Ghana. Currently, there are several institutions in Ghana where we have Ghanaians from different social, religious, political and economic backgrounds working together to ensure the

\footnotetext{
${ }^{27}$ Konadu, The Impact of Religious Pluralism on the Ghanaian Society: Case Study of the SekyereKumawu District in Ghana, p.95

${ }^{28}$ Ayertey, Mastering Social Studies, p.131

${ }^{29}$ Wiredu, Cultural Universals and Particulars: An African Perspective, p.26

${ }^{30}$ Busia K. A., 1962. The Challenge of Africa, New York: Praeger, p.104

${ }^{31}$ Ayertey, Mastering Social Studies, p.131

32 De Jong, Religious Values and Economic Growth: A review and assessment of recent studies

${ }^{33}$ De Jong, Religious Values and Economic Growth: A review and assessment of recent studies

${ }^{34}$ Chukwudum, Urbanization and African Traditional Values.

${ }^{35}$ Samwini, N. I., 2014. 'The Need for and Importance of Dialogue of life in Community Building: The Case of Selected West African Nations', Journal of Interreligious Dialogue, Volume 3, No 1.

${ }^{36}$ Ayertey, Mastering Social Studies, p.131
}

37 Kendall et al, Sociology in our times, p.77 
economic development of Ghana. This quality, if maintained, would help the country to enjoy sustainable economic development.

\subsection{Humility}

African Traditional Religion has rules and regulations, norms and taboos pertaining and peculiar to the religion. There are also some ethics and etiquettes determining good and bad actions. Humility is one of such lucrative values of African Traditional Religion. The Ghanaian traditionalists are particularly humble and this is evident in their greetings, interpersonal relationships and the willingness to render an apology when it is required. Humility does not mean inferiority or servitude; rather it is a sign of modesty and respect for others. ${ }^{38}$ Humility is linked with politeness. The traditional Ghanaian has the belief that God rewards or blesses the humble person. This virtue helps to raise modest people who are willing to contribute amicably and relentlessly to the development of their nation. Every human love to be welcomed politely wherever he finds himself. As such, people from different countries wanting to be respected and treated with modesty do come to Ghana to benefit from such lucrative traditional values. The foreigners come with resources and aids or grants to help in the economic development of Ghana.

\subsection{Hardwork}

Hardwork is a very important value inthe African traditional setup. On this not, Asante indicates that work, a category of economics, has always been part of the human history. ${ }^{39}$ For him, the Ghanaian musicologist said it all when he sang 'Odomankomaboade no, ode adwumabataannipa ho'. This means when the Eternal God created the universe, He assigned work to the human being. All of this is to say that the economic history of Ghana is nothing short of the history of the people of Ghana. The human's life is homo economicus just as the human is a religious being, homo religiousus. ${ }^{40} \mathrm{Gyekye}$ supports this by stating that the ethic that hardwork is a moral obligation and that human beings should acquire the habit of working hard is understood and practised in traditional African societies. ${ }^{41}$ Thus, economically, the activities of the traditionalGhanaian are stocked in the blood of religion.

As a result, the hardworking traditional Ghanaian goes through or performs some rituals before sowing new seeds during a new farming season. For instance, the KodaKpami rites of the Krobo people of Ghana precede sowing of new millet seeds; and also, others must be performed before harvesting of crops, for example Yam festival. Fishermen must observe the sacred days of the sea god to the latter. This gives them some rest and makes them resume work with vim and vigour. Shrines serve as banks where hardworking people can go for loan and ask for the blessing of the divinities. The ancestors and the gods are believed to be in charge of the land and hence reward hardworking people. In the African traditional religious setting, there are communal rewards in the form of praises and honour for those who exhibit hard work and punishment for lazy ones. The lazy ones are considered societal misfits. For Magesa, as far as the entire society is concerned, dignity means of course the absence of want. It means wealth in crops, animals and children. ${ }^{42}$ This stems from the belief in African Traditional Religion that every individual has a talent imbued in him by God his creator at creation. The individual is expected to be creative. Therefore, for Asante, our creative activities are sacred activities. In our work, we participate in sustaining God's creation. The human being was meant to be creative, to resemble God in His creativity. ${ }^{43} \mathrm{He}$ adds that when we work, we affirm our humanity. Thus, work is seen as a condition for progress and for money too. ${ }^{44}$ The Ewes of Ghana have maxims which go like 'the person who goes to draw water does not drink mud' and 'the person who comes round to lick the soup pot will never be filled'. These Ewe maxims means that only through hard work can you get what you want and enjoy the fruits of your labour. ${ }^{45}$ This conception and preoccupation informs the Ghanaian societies to organize themselves for activities individually or communally aimed at ensuring sustainable economic development in Ghana.

\section{Conclusion}

A religion that does not address the needs and wants of the practitioners and the human society in general is a dead religion and hence unworthy to be followed or practised. From our discussion, it can be realized that African Traditional Religion has much to offer in relation to means of ensuring sustainable development of our society. The values or virtues championed by African Traditional Religion if practised amicably can help ensure sustainable economic development of our human society. The traditional religious values have the ultimate aim of ensuring the success, survival, wellbeing and the smooth running of the community or human society as a whole.

\section{References}

i. Asante, E., 2007. Culture, Politics and Development: Ethical and Theological reflections on the Ghanaian experience. Ghana: Challenge Enterprise

ii. Asante, E., 1999. Stewardship: Essays on Ethics of Stewardship. Ghana: Wilas Press Limited.

\footnotetext{
${ }^{38}$ Ayertey, Mastering Social Studies, p.131

${ }^{39}$ Asante E., The Role of the Church in the Economic History of Ghana - Past, Present and Prospects. p.1

${ }^{40}$ Asante, The Role of the Church in the Economic History of Ghana - Past, Present and Prospects. p. 1

${ }^{41}$ Gyekye K., 1996. African Cultural Values: An Introduction, Accra: Sankofa Publishing Company. p.101

${ }^{42}$ Magesa, L., 1998. African Religion: The Moral Traditions of Abundant Life. $1^{\text {st }}$ ed. Nairobi - Kenya: Paulines Publications Africa. p.231

${ }^{43}$ Asante, E., 1999. Stewardship: Essays on Ethics of Stewardship. Ghana: Wilas Press Limited. p.32

${ }^{44}$ Chukwudum, Urbanization and African Traditional Values.

${ }^{45}$ Gyekye, African Cultural Values: An Introduction, p.103
} 
iii. Asante E., The Role of the Church in the Economic History of Ghana-Past, Present and Prospects. A lecture delivered by Prof. Emmanuel Asante.

iv. Ayertey I., 2002. Mastering Social Studies, Accra: Excellent Publishing and Printing

v. Busia K. A., 1962. The Challenge of Africa, New York: Praeger.

vi. Chukwudum B. O., Urbanization and African Traditional Values. Available at http://www.crvp.org/book/Series01/1-5/chapter_ix.htm.Accessed on 17/09/2018.

vii. Ebenezer 0. A.,2010. Science, Religion and Man, Daily Graphic newspaper: Ghana.

viii. De Jong E., 2008. Religious Values and Economic Growth: A review and assessment of recent studies. Available at http://www.ru.nl/nice/workingpapers. Accessed on 07/09/2018.

ix. Esther O. A., 2012. 'Building a Tension-free Society for Mutual Relationship: Our Religious Differences Notwithstanding', WAATI Papers No. 7 on Christian-Muslim Relations in West Africa

x. Gyekye K., 1987. An Essay on African Philosophical Thought: The Akan Conceptual Scheme, Cambridge: University Press

xi. Gyekye K., 1992.'Person and Community in African Thought' in Wiredu K. and Kwame, Gyekye (eds.) Person and Community: Ghanaian Philosophical Studies 1. Washington: The Council for Research in Values and Philosophy

xii. Gyekye K., 1996. African Cultural Values: An Introduction, Accra: Sankofa Publishing Company.

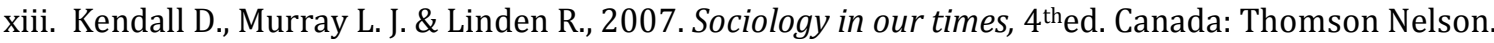

xiv. Konadu A., 2015. The Impact of Religious Pluralism on the Ghanaian Society: Case Study of the SekyereKumawu District in Ghana, UPK - KNUST.

xv. Magesa, L., 1998. African Religion: The Moral Traditions of Abundant Life. $1^{\text {st }}$ ed. Nairobi - Kenya: Paulines Publications Africa.

xvi. Mbiti, J. S.,1989. African Religions and Philosophy. 2nd ed. 361 Hannover Street, Portsmouth: Heinemann Educational Books Inc.

xvii. Mbiti, J. S., 1989. Introduction to African Religion, $2^{\text {nd }}$ ed. 361 Hannover Street, Johannesburg: Heinemann Publishers Ltd.

xviii. Samwini, N. I., 2014. 'The Need for and Importune of Dialogue of life in Community Building: The Case of Selected West African Nations', Journal of Interreligious Dialogue, Volume 3, No 1.

xix. Twumasi P. A., 1988. Social Foundations of the Interplay between Traditional and Modern Medical Systems,Ghana: Ghana Universities Press.

xx. Wiredu K., 1996. Cultural Universals and Particulars: An African Perspective, Bloomington and Indianapolis: Indiana University Press. 